\title{
PREVENTIVE CONSERVATION AS A PROCEDURE FOR SAFEGUARDING MOSUL BUILT HERITAGE
}

\author{
Emad Hani Al-Allaf \\ Lecturer, Dept. of Architecture, University of Mosul, Iraq. \\ E-mail: emadhanee@yahoo.com \\ (Received: 16/4/2013; Accepted: 15/9/2013)
}

\begin{abstract}
After the success of various international experiments of adopting preventive conservation approaches for safeguarding the cultural heritage such as Monumentenwacht Vlaanderen in Belgium, and Netherlands, and La consrvazione programmata in Italy, many countries attempt to put such strategies for protecting their heritage. During the last three decades or less, many monuments and heritage buildings in Mosul old city have been deteriorated progressively due to many factors the most important of which is the lack of monitoring and controlling procedures for preserving these irreplaceable outstanding constructions. Preventive conservation describes research and interventions aiming at reducing deterioration rates and minimizing risks to the constructions. It aims to identify and reduce potential hazards to cultural artifacts with thoughtful control of their surroundings, and it attempts to mitigate the occurrence of damage and deterioration through research and the implementation of procedures which enhance the safety of cultural objects and buildings. The absence of a comprehensible and efficient preservation protective policy for the responsible institutions of conservation of Mosul built heritage is a critical issue. The research aims to compare the current conservation policy of these institutions with international counterparts, and to put guidelines and recommendations for preparing a preventive conservation plan for the cultural heritage of Mosul Old City, which are represented by controlling its vital aspects such as managing of environment, risk, documentation, schedule investigation, information, regulation, human resources, and communication. The paper methodology adopts a comparative analytical study between several successful international experiments in preventive conservation field and the current existing procedures of the conservation of the Mosul built heritage.
\end{abstract}

Keywords: Conservation, Preventive Conservation, Practical Procedures, Built Heritage, Mosul Old City. 


\section{INTRODUCTION:}

The significance of the Built Cultural Heritage can only be sustained if the physical assets are appropriately and systematically maintained (Venice Charter, 1964, P.1-3). The concept of preventive conservation is confirmed by the Amsterdam Declaration which introduced the concept of integrated conservation that necessitates conserving the built heritage in its environmental context, with utilizing restoration techniques and searching for suitable functions (Amsterdam Declaration, 1975, P.3-6). Nowadays, in the field of conservation, assuring heritage preservation through preventive conservation, maintenance and monitoring based strategies is an acknowledged challenge ${ }^{1}$. There is an increasing evidence of the role that cultural heritage in general and conservation in particular, plays in creating a prosperous economy from encouraging the development of small and medium sized enterprises, to developing new technologies and markets, to encouraging tourism and inward investment (Cassar,2006,P.2). With the aim of returning a historic construction or heritage fabric into a good situation of repair, permanent identification and appropriate modification of defects can avoid subsequent harms that may call for extra resources and budgets. In the urban renewal process, profits of cultural heritage begin to be considered.

In Mosul old city, many monuments, heritage buildings and historical sites have been increasingly deteriorated in the three previous decades, due to the lack of monitoring and controlling procedures for preserving these irreplaceable exceptional constructions. The absence of a comprehensible and efficient preservation protective policy for the responsible institutions of conservation of Iraqi built heritage, generally, and the old city of Mosul, particularly is a critical issue. This paper assumes that such a policy lacks vital aspects which negatively affect the process of safeguarding the built heritage of these institutions. The research aims to compare the current conservation policy of these institutions with international counterparts through a study that comprises a theoretical part, by which Preventive Conservation, its types and requirements are reviewed (part I); and an analytical study that includes a review of successful international practices in preventive conservation, and next to determine the most important mechanisms for each of them so as to extract a set of standards and actions (part II) used in a comparison with policies of the local institutions, those responsible for maintaining Mosul built heritage, through performing specific semistructured questionnaire and interviews with the specialists in the field of heritage conservation in Mosul (part III), to determine the most important flaws and weaknesses of the local experiment, so as to provide a set of conclusions and recommendations to close the

\footnotetext{
1 Currently, at the international level, many organizations and groups deal with the field of preventive conservation such as The pan $\neg$ European Preventive Conservation strategy, the Latin American Consortium for Training in Preventive Conservation in which Getty Conservation Institute is working in partnership with conservation professionals and architects, ICCROM's Teamwork in Preventive Conservation, and PRECOMOS the UNESCO Chair.
} 
knowledge gap concerning the local preventive conservation policy and lost practical aspects for preserving the built heritage of Mosul old city (part IV).

\section{WHAT IS A PREVENTIVE CONSERVATION?}

Compared with traditional conservation, Preventive Conservation is relatively a new field. It is one of the most interdisciplinary fields as it refers to knowledge from materials science, building science, chemistry, physics, biology, engineering, systems science and management, as well as a host of technical fields (NGA website) $)^{2}$. Preventive conservation explains research and interventions intended to reduce deterioration rates and minimize risks to collections. It works under themes such as Environment, Risk Management, Physical Forces, and Materials (ICOM-CC website). Creating and maintaining a protective environment for the collections in their care is an essential responsibility of specialists. There is a general assumption that fine-tuned diagnostics can lower restoration cost (Torre, 2010C, P.4). When regular maintenance is carried out, the preservation of historic buildings will be more cost effective at the long run. As a result of systematic collection of information during the regular inspections (monitoring of the state of repair) it becomes possible to compare and monitor the state of preservation of the cultural heritage "stock". Collected statistic data can also be used as a management tool as well as for research (PRECOMOS website). Hence, Preventive Conservation is a critical aspect of conservation policy and collections care, since it focuses not only on the monuments but also on the entirety of the architectural heritage, and needs a conception of compound value systems within various cultures and an understanding of how cultural properties deliver significance to the involved groups.

\subsection{Definitions of Relevant Notions}

For the research purpose, several terms in the field of conservation of the cultural heritage should be defined. The following definitions have been given by the ICOM-CC Conference in 2008 (at the $15^{\text {th }}$ Triennial Conference in New Delhi):

Conservation: all measures and actions aimed at safeguarding tangible cultural heritage while ensuring its accessibility to present and future generations.

Preventive conservation: all measures and actions aimed at avoiding and minimizing future deterioration or loss.

Remedial conservation: all actions directly applied to an item or a group of items aimed at arresting current damaging processes or reinforcing their structure.

Restoration: all actions directly applied to a single and stable item aimed at facilitating its appreciation, understanding and use (ICOM-CC website).

2 National gallery of Australia website, in 25/1/2012. 
The resolution of this meeting has been included that "Conservation embraces preventive conservation, remedial conservation and restoration. All measures and actions should respect the significance and the physical properties of the cultural heritage item" (ICOM-CC website).

Preventive conservation encompasses appropriate measures and actions for registration, storage, handling, packing and transportation, security, environmental management (light, humidity, pollution and pest control), emergency planning, education of staff, public awareness, legal compliance (ICOM-CC website).

In the United Kingdom, preventive conservation is a part of the overall concept of stewardship defined simply as 'the sustainable use of collections', balancing preservation and use... Preventive conservation might be defined as 'the process of managing with others, the use and protection of cultural heritage for the benefit of today's audiences and future generations (Cassar, 2006, P.1). It can be defined as meaning all indirect actions aimed at increasing the life expectancy of objects and collections (VANTAA, 2000, P.2). It is any measure that prevents damage or reduces its potentiality (Reccia, 2009, P.35). The scope of preventive conservation is large that it extends between inspection and daily protection of elements and strengthening constructions in seismic zones in an attempt to prevent additional harm by utilizing all techniques needed to effectively monitor alterations, besides the use of appropriate materials for preservation purpose. Because preventive actions principally consider the recognition and understanding of the individual, it includes heritage management and the participation of all stakeholders. Stefano Della Torre argued that shift from restoration to preventive conservation is an innovative attitude which gives a good idea of what we mean when we say that preservation field can improve its performance (Torre, 2010C,P.6).

Aforesaid, Preventive Conservation can be defined as all measures that prevent damage or reduce its potentiality, with all efforts to preserve cultural heritage by controlling their environment in which they are displayed, stored or transported. Preventive Conservation intends to concentrate on practices of preventing or decelerating the deterioration of objects by controlling the built heritage environment, and by focusing on collections rather than individual objects, urban fabric rather than the individual monument, non-treatment rather than treatment.

\subsection{Types of Maintenance:}

There are two kinds of maintenance activities, preventive and curative maintenance (Kenkel, 1994, P.313-316) (Massue \& Schvoerer, 2001, P.2-25) (Reccia, 2009, P.124-126):

1. Preventive maintenance is directed to prevent eventual problems. It is related to the 
previsions about the supposed natural ageing and about the expected anomalies. The timing and the frequency of preventive and completing maintenance can be expected. There are two kinds of operations of preventive maintenance: Real preventive, like protective treatments on materials or the decisions about limitation of use; and Protective, typically the insertion of an element to preserve others. Generally, preventive protective activities are measures already established by the restoration project and maintenance and monitoring have to be planned to keep them efficient and to evaluate their efficacy.

2. Curative (Remedial) maintenance is directed to correct the problems occurred. It is due to the anomalies relieved by controls and its scheduling depends on the monitoring results. The timing of curative and corrective maintenance is related to the survey of the phenomenon to take care. The planning is mainly about controls to establish the necessity of curative and corrective interventions and to tune the frequency of preventive and completing maintenance.

\subsection{Discipline and Field of Preventive Conservation}

According to ICCROM ${ }^{3}$, the activities of the Preventive Conservator revolve around: Environmental monitoring to ensure appropriate conditions: temperature, relative humidity, air quality, and light; Integrated pest management to protect works of art from damage; Implementing handling and maintenance procedures for storage, exhibition, packing, and transport of works of art; Disaster preparedness for the collection; Collection protection for special events and activities; Assessing loan venues and assisting regional galleries with preventive conservation, and; Encouraging participation and teamwork from all staff to achieve preventive conservation goals. The preventive conservation scientific research framework includes four series levels: 1) identifying threats to collections, 2) substantiating the risk, 3) identifying cost-efficient means to measure the risk, and 4) developing methods to reduce or eliminate the risk (The J. Paul Getty Trust website).

\subsection{The Main Maintenance Strategies}

The main maintenance strategies differ in their timing (Reccia, 2009, P.13-18) (Sullivan et. al, 2010, P.56-58) ((FMP, 2012, P37-38) :

1. Emergency or accidental maintenance: it concerns unpredictable damages and it is carried out when the damage occurs. It is not a part of the planning and it can be avoided by a rightly planned preventive maintenance.

2. Preventive-predictive threshold maintenance: It is formed by all of the maintenance actions regularly made on the basis of historical and experimental data. This strategy depends on the possibility to discern with certain reliability the durability of the different components 
and of the system and the probabilities of damage. This kind of maintenance results is adequate for those situations with a high level of criticality, whose objective is their constant conservation and whose durability and damage rate are known.

3. Preventive maintenance condition-based: It is constituted by operation of preventive maintenance following the knowledge about durability and life-cycle related to monitoring results; on the basis of monitoring results it is possible to modify the operations planned and their frequency .Thus, the real object of the scheduling is the monitoring itself upon which maintenance depends. It is very effective when it is applied to historical buildings, particularly if they are of great cultural value, because an irreparable damage could have a cost not quantifiable or at least much bigger than the one necessary to guarantee a constant monitoring. Moreover this strategy is also particularly suitable for interventions of restoration and especially of consolidation.

4. Opportunity maintenance: the whole operations are done in advance on the occasion of opportunities that allow to attribute to one other cause their convenience; the aim is to exploit installations and resources already mobilized for others interventions or to seize the opportunity given by a sudden necessity of intervention on others parts of the building. The preventive-opportunity actions have to be in any case previously evaluated on parameters linked to the life cycle of the element that has to be repaired. Because it joins in one session different interventions, it lets to save economic resources, thus reducing the cost, just in case it is well conducted.

\subsection{Preventive Conservation Requirements:}

As a part of conservation of cultural heritage, preventive conservation requires a change in attitudes and habits. Understanding what preventive conservation means is the initial stage of awareness; then accepting it as a legitimate collections care strategy. Next stage is when preventive conservation becomes an integral part of an institution's perception and is put into practice routinely. It requires the assessment of objects, deterioration agents, and the environmental context (surveys and investigations); as well as long-term judicious management and forward planning (Salzwiki website).

Preventive conservation requires common solutions based on the application of science. This is achieved through collaboration based on mutual understanding between different disciplines. It is interdisciplinary, relying on mutual and reciprocal action between different branches of learning. We need to make links between mainstream societal concerns, such as health and education and preventive conservation. Both health and education are key indicators of quality of life. Cultural heritage, underpinned by sound preventive conservation, 
is an important contributor to improvements in quality of life. It has a part to play in improving health and education of our citizens (Cassar, 2006, P.1). ${ }^{4}$

\subsection{Benefits of Preventive Conservation}

If the main part of the built heritage is to remain to exist, it has to be safeguarded as a group rather than as individual monument in isolation. Usually the conservation activities of built heritage encompass some problems: values assessment, costs and benefits of restoration and maintenance techniques, funding policies and regulations; the high cost of restoration, the always increasing demand for funding, the often arbitrary definition of values and priorities, the uncertainty of sufficient revenue to cover costs of maintenance and property management, many restorations are undertaken without any worry about the future. Furthermore, many development projects have never been assessed nor monitored, and many times funds given to deprived territories did not produce any development, but just fed and strengthened local forces working against innovation (Torre, 2010C, P.1).

In the process of conservation built heritage, principals such as integrity and authenticity are essential, thus, to guarantee these principals, guidelines for such activity should designate a number of standards that must be appreciated during the managements until final interventions.

Prevention always has to do with an attention paid to context as well as to its evolution through time. As the conceptual framework takes becoming as a condition of human existence, prevention does not aim at the illusion of steady conservation of built heritage, but at improving the management of transformation (Torre, 2010A, P 68). The supreme approach to conserve historic buildings or sites is to keep them in use, hence, due to its potentialities, preventive maintenance has been proven to be the most appropriate for achieving the objective of conserving built heritage, since it is necessary to adopt a policy that has the lowest amount of interventions in order to preserve integrity and authenticity, as well as maintenance that assists functional continuity of building and contributes in its safeguarding versus risks.

Maintenance procedures should be executed to keep the authenticity of the heritage, since treatments are related to authenticity in materials and staff skills. Assurance preserving of the economical, architectural and particularly cultural and historic values of built heritage is the key idea of managing cultural resources, thus a thorough preservation strategy that comprises conventional inspections is required. Currying out preventive actions as practices

\footnotetext{
${ }^{4}$ No innovation is produced, and no hidden resource is unrevealed, if there is no rule, and subsequent control, to force local system to learn new lessons, to change mind, to find out its own way to innovation. Furthermore, no increase in performances will be sustainable and will last long unless there is an enhancement of local rooted leadership and management resources (S. Della Torre, 2010C, P.9).
} 
of materials treatment has many profits including extending lifetime of the original materials and structures, protecting them in the original position and safeguarding the age value retaining the traces of its history (Reccia, 2009, P.34).

\subsection{Deficits and Limitations:}

Occasionally, preventive conservation actions do not verify success and can themselves be harmful and speeding up building deterioration. In the case of historic buildings, carrying out unsuccessful alterations and additions perhaps cause greater damage. ${ }^{5}$

\section{EUROPEAN EXPERIMENTS IN PREVENTIVE CONSERVATION}

In last decades, in Europe, new attention of maintenance is increasingly developed, with the diffusion of preventive, integrated and planned conservation ${ }^{6}$. Herein, a preview of principals and potentialities of several experiments about preventive conservation are analyzed:

\subsection{PRECOMOS the UNESCO Chair}

PRECOMOS is the UNESCO chair on preventive conservation ${ }^{7}$. It aims at identifying research and educational activities in the field of preventive conservation, maintenance and monitoring of monuments and sites, so as to contribute to: Identifying the particularities of preservation policies and practices; Developing new appropriate tools and techniques to improve preventive preservation strategies; Developing legal frameworks, policies and exemplary field applications considering the variety of cultural and social contexts ${ }^{8}$ (PRECOMOS website).

\subsection{Conservazione Programmata, Lombardy Region, Italy}

The principal restoration campaign has been carried out for the sake of beauty and historical appearance, forgetting seismic risk. The lesson learned after L'Aquila quake is a challenge to traditional vision of restoration, in terms of criteria and priorities. It is not new: from the mid1970s in Italy there are talks about "conservazione programmata" (planned conservation), claiming priority for prevention and maintenance, that is for process innovation (Torre 2010C, P.9).

\footnotetext{
5 In the other hand, the successful implementation of preventive conservation measures presumes knowledge of the object, which in turn requires object assessment and ongoing monitoring both of the object and the microclimate. This is difficult to achieve. A range of options can be considered; from the cheap to the expensive; from the more easily implemented to those which are difficult to implement; from those which are directly achievable to the aspirational (Salzwiki website).

${ }^{6}$ For instance, it is mandatory for all the public projects in Italy to systematize a maintenance plan.

7 The UNESCO chair on preventive conservation, monitoring and maintenance of monuments and sites has been established at the RLICC (K.U.Leuven) in collaboration with Monumentenwacht Vlaanderen (MWVl) and the University of Cuenca (Ecuador).

8 On 24 March 2009, at the inauguration ceremony keynote speeches addressed the nature and importance of preventive conservation. On the 25th of March, three thematic seminars were organized to promote academic exchange on topics related to preventive conservation, maintenance and monitoring of monuments and sites. International best practices in this field were also presented.
} 
In Italy, considering especially the maintenance activity, in collaborating with the Politecnico di Milano, Lombardy region prepared the guidelines for the planned conservation of the heritage, basing on the Risk Card (Carta del Rischio) of Cultural Heritage to create the conservation Plan (La Conservazione programmata) that mandatory to be adapted to the historical buildings. It emphasizes that the objective of the conservation of the historical architectural heritage can be achieved by combining restoration and planned maintenance. ${ }^{9}$ In 1999, Politecnico of Milano became partner of Regione Lombardia in some researches about maintenance of historic buildings, inside the policy of establishing the Risk Map of Cultural Heritage in the region. This collaboration has two important outcomes: Guidelines to make maintenance plans customized for historic buildings; and Software SIRCOP, which is an Information System finalized to make maintenance plans of Built Cultural Heritage (Torre, 2010B, P.47-52) (Sessa,2000,P.1-3).

\subsubsection{SIRCOP Software (Regional Information System for Planned Conservation):}

The regional software SIRCOP is new Maintenance Management System software made by Lombardy Region developed within a larger project on planned conservation which help the experts to prepare plan, and it allows exchanging of information between experts, workers and authorities. SIRCOP has been designed to support the designer in filling out the maintenance plan, during and after the restoration project. As Italian legal framework, at the moment, enforces the maintenance plan during the project phase, but does not make maintenance mandatory, there is the risk that maintenance plans could be only drafted, and then abandoned as papers without any usefulness.

The document made up by SIRCOP is not a static document, but an information system which can be updated and implemented, giving guidance and some aid to make maintenance happen. In fact, the software is definitely different from commercial software: it has been thought expressly for Built Cultural Heritage, so that it enables to describe the diversity of elements which can look like similar. SIRCOP's logic is focused on "critical issues", both for conservation and performances of technological elements (Biagini, 2002, P.96-100). From each critical issue of every element, the specifics come out for inspections (where and what to look), for activities and procedures (what to do, when and how), for the evaluation of costs. From 1999, it has been tested in different pilot cases and also some dissemination and training for professionals and owners (Fig.1, Fig.2).

\footnotetext{
${ }^{9}$ In Italy, in 1999, the new laws concerning Public Works (Law $109 / 94$ and Decree 554/99) introduced the maintenance plan as a necessary part of any project. In 2004, this document was confirmed for Public Restoration Works (Decree 30/2004). But in the regulations of Public Works, and then in the commercial software put on the market, there is no difference between new and historic buildings (SPRECOMAH website).
} 
3.3 MonumentenWacht ${ }^{10}$

Currently, in some European countries there are organizations specialized in the field of monument inspection. This development began in the 1970s in the Netherlands, when Walter Kramer, an architect for the Dutch National Department for Cultural Heritage, came to the conclusion that there was a restoration cycle for monumental buildings, particularly the larger ones, of between 25-30 years. He argued that if a monument can be kept in good technical condition through regular maintenance once it has been restored, then a new restoration, while it remains an inevitability, can be postponed for a significant amount of time, and this would save a lot of funds. He started a small organization, which inspected monuments and advised the owners on how they should maintain their valuable property. It started as an annual inspection and first aid repair service, by subscription, for a small group of private listed building owners, who felt they didn't have the appropriate skills or knowledge to undertake this for themselves (Dann, 2000, P.2). This concept, though simple in nature, turned out to be a masterstroke in practice. Not long after that, interest in the Monumentenwacht formula began to arise in other countries as well. Today there are more or less comparable organizations working in Belgium (Flanders), Germany, Hungary, Denmark and England. A growing number of European countries, for instance France, Italy, Spain and Scotland, are interested in starting up similar organizations (SPRECOMAH website).

From its very inception, three concepts have been central to the Monumentenwacht: expertise, impartiality and independence. Over the years, no concessions have been made to these three key concepts; The Dutch Monumentenwacht is an organization that primarily works for the owner of a monument. Its activities are collectively financed in the Netherlands by both the national and provincial authorities as well as the owners of the monuments themselves. The inspection of a monument should be seen as the first step in a maintenance, improvement process, the preservation of a monument. Regular inspection and small scale maintenance works can help prevent major disasters, for instance as a result of long-term leakages; such difficulties are quickly identified and remedied during an inspection (Fig.3, Fig.4).

The deterioration of a monument actually begins the day after the restoration is completed; a blocking gutter may result in substantial damage. In this context, the adage 'prevention is better than cure' is definitely applicable. The outcome of an inspection consists in an observation report containing recommendations for further steps to be taken and improvements to the monument. An added advantage is that minor maintenance tasks can be

\footnotetext{
${ }^{10}$ Monumentenwacht is at the moment the largest organization in the field of the maintenance of cultural heritage in the Netherlands. The concept received several international awards, for instance the European Union / Europa Nostra prize for cultural heritage. With years of maintenance cost to a user Monumentenwacht document providing that the members help the cost of maintaining their property to estimate and plan.
} 
carried out in situ during the inspection itself, naturally on the condition that those performing the inspection have been adequately trained for this. The observation report may also include directions for carrying out well-considered maintenance or restoration work on the monument (Monumentenwacht website).

\subsection{SPRECOMAH}

Within the Sixth Framework Program of the European Commission and in the context of the SPRECOMAH project, on preventive conservation and monitoring of architectural heritage two seminars have been organized ${ }^{11}$. At SPRECOMAH, some examples of practices deeply related to preventive conservation are identified and presented, which consent to evaluate various methodologies and instruments:

\subsubsection{MDDS - Monument Damage Diagnostic System}

MDDS is a (prototype) decision support tool, as well as a knowledge based system (or expert system). It is meant for description and evaluation of the state of conservation of historic buildings; analysis of the origin of damage found; planning of conservation techniques, when necessary. It is meant for professional organizations in charge of the monitoring of monuments; administrators or owners of monuments, like the organizations in charge of the care of monuments, local authorities; policy planners in this area, through targeted policy modules; and education e.g. restoration architects.

MDDS provides the professional users with knowledge and support, enhancing their expertise. It contains a complete damage atlas for historic building materials, as well as a dictionary of damages in different languages; the system is furnished with background information concerning damage processes and techniques for intervention. It generates reports on the state of preservation of a building and the planned conservation measures, the reports can easily form an archive of investigated monuments and it offers support in making a correct diagnosis of the damage. It makes it easier to evaluate techniques for interventions and to limit the costs of the interventions, avoiding unnecessary or wrong measures, and it is also a monitoring tool, MDDS is constantly furnished with new knowledge by TNO; knowledge derived from EU projects is provided as a basis for facing practical problems ${ }^{12}$ (SPRECOMAH website).

\subsubsection{D Representations of the Historical Heritage:}

\footnotetext{
11 The first seminar took place in Leuven, at the Catholic University of Leuven (Belgium) between 11 and 16 June 2007 the second Sprecomah seminar was organized in Val de Loire, at the Fontevraud Abbey, (France)26-31 May 2008.

12 For future developments MDDS is a prototype, which will be developed into a MCDS (Monument Conservation Diagnostic System), that is to say a monitoring instrument for preventive conservation. A friendly user interface will be provided and the following will be included more building materials (timber, concrete); knowledge on structural behavior; and 'policy support' tools.
} 
The technologies applied to Cultural Heritage and in particular, the 3D reconstruction of sites and monuments, allows replacing the past in a non-invasive method. In this way, it is possible to make both virtual restorations and a capillary communication of the cultural contents that is the first step of the Cultural Heritage preventive conservation. Many attempts have been performed and different projects have been realized in this field, e.g. in Italy, the realization of the Virtual Museum of the ancient Via Flaminia with the aim of the "reconstruction of the archaeological landscape of the ancient road with virtual reality systems" (Fig.5).

The real time application, permanently exhibited in a multimedia room at the National Roman Museum of Rome, is a digital ecosystem that implied a hard work on the multidisciplinar data behind the more impressive VR modelling. It focuses on a first wider level scale consisting of a holistic vision of the road from Rome to Rimini and based on historical maps, information on the archaeological excavation, technical cartography and aerial and satellite photos able to support the realization of a web GIS; and a second level of detail based on five contextualized monographic areas. Integrating the top-down process with the bottom-up ${ }^{13}$ it has been possible to reconstruct the ancient landscape. Thus, virtual archaeology is able to connect the present archaeological landscape with the ancient one through a methodological process which is always transparent: although the ancient world can be neither reproduced nor reconstructed, virtual archaeology tries to rebuild the developing contest that the time has erased (SPRECOMAH website).

\subsubsection{Non-destructive techniques of analysis:}

Non-destructive testing (NDT) uses different physical principles, methods and sensors for getting information about external and internal structure and material properties. Generally, NDT applications should be a part of the global investigation of historic buildings. They do not replace other investigation techniques completely but in the case of historic monuments, NDT should be preferred instead of traditional tests on extracted samples when both types of techniques can solve the problem. ${ }^{14}$ Depending on the particular situation and question, NDT methods are useful to get a first survey of large areas at the beginning of building reconstruction or restoration projects namely on structures with defects or damage. It is then possible to investigate surfaces and parts of protected historic constructions or areas, which are difficult to access, with higher precision. These techniques can also be applied for long-running observations (monitoring) or be used as quality-assurance after repairing interventions and during historical building researches.

\footnotetext{
13 Through the data acquisition with different techniques as laser scanner, photogrammetry and so on.

14 Currently, commercial systems or specifically developed systems like ground penetrating radar (GPR), impact-echo, sonics, microseismics, acoustic emission, geoelectric, active thermography and flat-jack have been applied successfully.
} 
With NDT methods, information is gained about irregularities within the historic structure, which itself is often inhomogeneous. Irregularities may derive from constructive mounting-parts (anchors, dowel, bars, and nails), differences in material (brick, stone, mortar) or microstructure, from voids (chimney, unfilled joints) or delaminations, cracks, salt or moisture influence or differences of loading. Damage and deterioration of material might be related to complex environmental influences (pollution, sun, rain, freeze-thaw, ground water) and environmental hazards (fire, storm, flood, and earthquake). In several cases, the combination of different methods is required (Fig.6, Fig7).

\subsubsection{High definition digital monitoring of architectural surfaces}

High definition digital photography and Laser scanning up to a height of $25 \mathrm{~m}$ for periodic monitoring of surfaces, without the use of scaffolding. It is High resolution digital 2D and 3D recording with a remote controlled mini-crane up to a height of $25 \mathrm{~m}$ (Fig.8).

Professional lighting and colour controlled images enable monitoring inside historic buildings. With a specially adapted mini-crane construction (patent pending) the result of a research project; Reaching recording Standards (RRS) University of Bamberg 2006-2008; a 39 Mega Pixel digital camera and two flash heads are lifted up to take colour controlled images for conservation and monitoring. The whole system is remotely controlled from the ground and can be set up by two people in approximately 1 hour. The compactness of the crane allows the access through standard doorways and use in restricted spaces. The remote controlled 3D head can hold a payload of 30kg. Further, non-contact recording devices, such as a 3D Scanner or an IR Thermography camera for the detection of detached plaster or moist can be attached (Beckett, 2008, P.2).

\section{ANALYZING THE EXAMPLES AND PROPOSING THE PROCEDURE}

By analyzing the international experiments examples, and for producing an active plan of preventive conservation of Mosul cultural heritage, a number of essential aspects might be highlighted and should be taken into account, that, generally, preventive conservation for the cultural heritage is involved in two main fields, Collections in Museums, and Built Heritage. This paper concerns the latter. As activities of preventive conservation include: registration, storage, handling, packing and transportation, security, environmental management (light, humidity, pollution and pest control), emergency planning, education of staff, public awareness, legal compliance, hence, for the proposing procedure, its main aspects can be classified as (The Management of) (Fig.9):

- Environmental Management : Environmental control;

- Risk Management : Preparing emergency planning; 
- Documenting Management : Registration Listing and reporting;

- Schedule Investigation Management : Inspections diagnosis and surveys;

- Information management : Information exchanging and representing;

- Regulation Management : Law, amendments and legislations;

- Human resources Management : Training, teaching and educational aspects, and;

- Communication Management: Public awareness and media.

\subsection{Preventive conservation characteristics}

Suggesting the procedure needs understanding and deriving preventive conservation principals and its characteristics. Following a number of its aspects:

4.1.1 The recommendations of ICOM-CC Conference in 2008, New Delhi, describe the characteristics of the measures and actions of preventive conservation as: They are carried out within the context or on the surroundings of an item, but more often a group of items, whatever their age and condition; they are indirect - they do not interfere with the materials and structures of the items; and they do not modify the appearance of the objects (ICOM-CC website). ${ }^{15}$

4.1.2 Uncomplicated and inexpensive strategies: Preventive conservation does not, at all times, require costly or difficult care strategies. In various cases, much can be attained by applying common sense. ${ }^{16}$

4.1.3 Interdisciplinarity: in a project, interdisciplinarity can be worked on three levels: by establishing a network that supports preventive conservation throughout a museum, by creating links among the staff of participating museums and by reaching out to involve the public in preventive conservation ${ }^{17}$ (Cassar,2006,P.3). Preventive conservation is an interdisciplinary activity and requires teamwork with conservation professionals - managers, fund-raisers, architects, conservators, geologists, chemists, engineers, etc., working together with the non-professional stakeholders - owners, local people. (Putt.et al, 2004, P1-2).

4.1.4 The unseen impact of preventive conservation: preventive conservation outcomes are not simply calculated due to the fact that in general the progress of deterioration is slowly in a built heritage make it not completely considered (excluding over time), and because

\footnotetext{
${ }^{15}$ Hence, they differ from the remedial conservation actions that latter are only performed when the objects are in such a weak condition or deteriorating at such a rate, that they could be lost in a relatively short time, and sometimes these actions change the appearance of the objects. Removing weeds from mosaics, dehydration of wet archaeological materials, and stabilization of corroded metals are cases of remedial conservation. While the measures and actions of preventive conservation differ in that restoration is only carried out when the item has lost part of its significance or function through past alteration or deterioration, and most often such actions modify the appearance of the object, and they are based on respect for the original material.

16 Building preventive conservation can be served by regular schedule maintenance; by securing that openings and roofs are in good repair moisture destruction can be prevented; using an adequate techniques enhance ventilation and air circulation; keeping spaces clean and free from dust is essential.

17 The greatest change to preventive conservation practice over the last decade is the extent to which it is now the product of the interaction of different professionals.
} 
preventive conservation does not involve enhancing the construction facades, deterioration rate is difficult to quantify.

4.1.5 Public awareness: Preventive conservation has the opportunity to tap the fascination and interest of the public in the process of protecting cultural heritage and to become a source of learning as well as enjoyment. Breaking down barriers between professionals and the public and raising public awareness strengthens the case for economic and political support for the protection of cultural heritage (Cassar, 2006, P.3). ${ }^{18}$

4.1.6 Involvement of the properties owners: that is, the owners of the heritage buildings assist the safeguarding cost of their property to estimate and plan.

\subsection{Preventive conservation aspects and the required actions}

Aforementioned, for achieving the research goals, the main aspects and the required actions of the preventive conservation to be tested, could be determined as shown in Table.1.

\section{THE CASE STUDY, POLICY OF CONSERVATION OF MOSUL BUILT HERITAGE}

(Current situation of the Preventive conservation of Mosul old city)

In the previous three decades or less, many monuments and heritage buildings in Mosul old city have been deteriorated progressively due to the lack of monitoring and controlling procedures for preserving these irreplaceable outstanding constructions. The major part of efforts of the preservation of built heritage of Mosul old city is carried out by each of the Directorate of Antiquities and Heritage of Nineveh and the Sunni Waqf in Nineveh, besides relatively less contribution of other institutions that depends on its entrusted responsibilities. For examining purpose of the current situation of the maintenance and conservation activities of Mosul heritage, involved participant bodies should be identified those carrying out such operations, as the government institutions perform the major part, and these institutions include the Directorate of Antiquities and Heritage of Nineveh, the Directorate of the Sunni Waqf in Nineveh, Municipality of Mosul, the Directorate of Nineveh province, and the Directorate of Urban Planning. Other institutions also contribute in supervisory or supporting role such as the University of Mosul, the technical institutes and bodies of the Ministry of Interior and other research or service institutions.

Consequently, for the research problem, interviews with the specialists (Architects, Engineers

\footnotetext{
18 Public opinion of a museum's work is now vital for some aspects of financing. User satisfaction is now a performance measure in national and local authority museums. Commercial sponsorship and private donations are likely to be founded on the donor's belief that the museum still has an informative and custodial role in contemporary society (M. Cassar, 2006,P.3).
} 
and archeologists) were performed, and a questionnaire (Appendix.1) was formulated ${ }^{19}$ to determine potentialities and limitations on the implementation of preventive conservation process on the Mosul historic and heritage buildings. The questionnaire is designed in a semistructured manner, by introducing some questions directed to study the research problem with giving interviewees the opportunity to express their comments and observations and extend in explaining their responses.

\section{DISCUSSION}

The questionnaires were collected and analyzed regarding the answers provided by participants. Concerning preventive conservation process within the action Plan of Architectural Conservation of cultural and historical property of the old city of Mosul, responses of departments officials included that despite the number of methodological characteristics of primary preventive maintenance through the implicitly availability of some aspects, as performing and providing their records, it lacks many aspects of the task needed to make it a methodical plan for preserving heritage buildings and archaeological sites, and as follows:

Firstly, all official participants emphasize the absence of preventive conservation in the planned conservation procedures, and the lack of periodic surveys and inspections on historic buildings except several very important constructions and monuments that do not exceed the number of hand fingers.

\section{- Environmental Management (Environmental control)}

The evaluation of environment is the initial phase for environmental modification, which might include a survey measurement monitoring and analysis of the environmental sources such as moisture, liquid water, air and surface temperatures, relative humidity, sun and artificial, light, air pollution, salts, and insulation. The degree of ventilation and heating within historic properties requires careful consideration. Moreover, thermodynamic modelling of the behaviour of the salt-system present with respect to environmental parameters can give useful information as to whether a certain relative humidity/temperature regime might be beneficial or harmful (Salzwiki website).

The officials in the Directorate of Antiquities and Heritage stressed that preserving works are limited on the curative maintenance that addresses the damage after it occurs in the restored building and does not extend to its urban fabric, and Restoration is the dominant 
policy in their conservation activities that restricted to restoring the building to its original state as much as possible, with the lack of a future plan for its rehabilitation in qualified its architectural function and the significant heritage value, beside absence of installing new technologies that help prolonging its age and reduce the extinction risk through controlling and treating its environments and micro climate. Hence, the monument turned into a dead Non-interactive building with its society and environment. Also, the lack of environmental studies of buildings micro climate or their area leads to inactivate controlling and managing the climate factors and its utilizing to get better results for the preventive maintenance service of the building firstly, and remedial preservation secondly.

\section{- Risk Management (Preparing emergency planning)}

Risk Map is an approach to deal with probably exposed risks to historical and heritage property. Although it is the most important preparations to be configured for the purposes of effective preventive conservation, the conservation plan does not include such methodology for any involved institution or department, with fact that international experiences have been passed large stages for a long time in this field such as Italian experiment and others. Many lacks and limitations inherent this aspect as most officials confirmed, e.g. there is no planning and programming maintenance procedures, lack of the appropriate number and efficiency of the maintenance and preservation staff, the involving directorates do not have sound relationships with each other or with the related governmental institutions to serve the conservation activities.

\section{- Documentation Management (Registration Listing and reporting)}

This aspect encompasses many obstacles and problems of registration, listing and reporting activities before the maintenance work, which is considered a vital aspect of preventive maintenance, as most of the conducted interviewees pointed out to the weakness of the classification and assessment of heritage buildings, lack of standards and criteria of heritage value assessment, the shortage of specialists staff that adequate for such complicated task within the cadres of the departments. In addition, lack of automated databases for all historic buildings and archaeological sites, lack of the records which collects the significant historical constructions, location and sites in the city.

\section{- Schedule Investigation Management (Inspections diagnosis and surveys)}

This aspect includes inspections, diagnosis, and periodic surveys, which, according to participants in the questionnaire included many shortcomings in many parts, such as lack of surveys and its related processes, lack of information for the successive surveys as descriptive or graphics forms, the lack of reports of the frequented type of damage for different historical, heritage facilities that are working to determine the treatment before destruction happens, there are no records of remarks and observations of the surveys conclusion in 
special reports, the lack of previous recordings rates of maintenance activities of buildings, the absence of the annual inventory for listing and registering the heritage buildings, inefficient of estimating accuracy of the date of defects appearance, unavailability of statements to determine the date of defects appearance in the building and its quality, rarely development of tools, techniques and instruments in line with global growth in the survey and maintenance field as a result of inappropriate budget or the lack of specialists staff, inadequate and inefficient minimum maintenance and repairs documents, the lack of surveyors, the scarcity of the damage detection search for the origin construction in predetermined time and for all essential elements, and the absence of a private consultation body that offers voluntary technical and engineering advices about maintenance work to the owners of cultural property, whether for public or private sectors. ${ }^{20}$

\section{- Information Management (Information exchanging and representing)}

With the global race in the development of digital technologies and advanced techniques used in managing, organizing and exchanging information databases, the current state of the local institutions is still far from the level of ambition supposed to reach it. This aspect significantly lacks the active substances for the preventive conservation due to what the role of provided information of the buildings play in facilitating the decision-making process of many of practical procedures. Participants noted the weakness in the financing and personnel expertise in this area that is not suitable with the services that could offer to carry out efficiently preventive maintenance.

These difficulties included the lack of digital information system for managing the heritage and historical properties ${ }^{21}$, lack of cooperation with specialist institutions to create specific software used for the purposes of heritage buildings information management, all departments do not have a permanent website which used to communicate with relevant authorities for the decision-making purposes $^{22}$, nor any Directorate has a website to communicate citizens to display updates and new developments, to give advices or to inform system and regulation changes, digital documentation media used in a preliminary way, any directorate did not attempt to form a digital map that can be reviewed by users, and used to demonstrate the names locations and information of current heritage buildings or archaeological sites in different periods of time.

\footnotetext{
${ }^{20}$ Furthermore, participants mentioned that in spite of the role of engineering supervising and management assume to play a key role in the conservation process, but it is noticed that this role does not activate properly, especially with the lack of the statements for determining the maintenance work to be carried out on the restored buildings, lack of the statements to determine the size of the maintenance work and its required costs needed for implementation, the lack of the statements to determine the number and quality of labors required to perform the tasks, the luck of the statements for the identification of time required to complete each activity of the maintenance, and the lack of the statements to determine the materials and services required to execute such work.

${ }^{21}$ Typically, the administrative agencies do not draw policies and strategies to develop their information resources and to stimulate the usage of information systems.

${ }^{22}$ which is usually used for coordinating aim between the various parties and responsible bodies of the heritage buildings, with the fact that usually the individual Directorate need to other government institutions for carrying out surveys and giving professional advices.
} 


\section{- Regulation Management (Law, amendments and legislations)}

Regarding to legislative and legal aspects, the participants agreed on the inadequacy and defectiveness of existing regulations to deter transgressors on the archaeological and heritage buildings, and that the maintenance legislations are inappropriate or insufficient. They demand enacting more favorable and constructive legislations that support protection process of heritage buildings such as increasing penalties for abusers to heritage buildings, and the positive involving of the competent authorities in protecting the built heritage such as the Ministry of Interior in real cooperation with the directorates to strictly implement laws that prohibit abusers from continuing to destroy the historic architectural resources in the city. This aspect also included an indication to the lack of funding for preservation, claiming enhancing financial support by government and private sectors for the maintenance, reducing or deleting the tax for owners of heritage buildings who are maintained their properties in a regular basis, giving grants or loans to owners of heritage buildings to carry out periodic maintenance, enacting laws contribute to the emergence of non-governmental institutions of preservation and safeguarding the cultural property.

\section{- Human resources Management (Training, teaching and educational aspects)}

As Della Torre stated that most of heritage conservation market consists of public works which have significant criticalities, for example, they suffer of uncertainty and delays as contracts are not complete: in works concerning heritage properties this is often the case, as many surprises arise even when a lot of diagnostic investigations are made before the project, but more often because projects are drafted by architects lacking the specific competences (S. Della Torre, 2010C, P.4). A good number of the participants confirmed in their answers the importance of specialized staff in carrying out the maintenance and preservation, and they noted to the small number of staff and its lack according to required amount of missions to be done, also highlighting the seriously lack of Directorate relationship with local technical skills and traditional crafts, any Directorate does not have records of professions and special craftsmen state of traditional and heritage construction, any practical training courses with the assistance of traditional craft for new technicians has not been executed in order to sustain heritage skills, as well as rarely performing of workshops for Directorate staff inside the country particularly for competencies improvement of preventive conservation.

Furthermore, the lack of recent studies and researches on the preservation and maintenance at the Directorate, for the purposes of competencies improvement and development of efficient staff generally in conservation policies and particularly in preventive conservation, it is clear that the lack of cooperation initiatives with foreign expertise and organizations, unavailability of abroad scholarships for the staff, with a few 
workers training sessions in the local archaeological and heritage studies and researches centers on using computers, management information systems and different useful software. In addition to the absence of advanced scientific technical disciplines in high graduate and undergraduate studies in universities and institutions in the field of buildings maintenance in general and the preservation of historic buildings, in particular. ${ }^{23}$

\section{- Communication Management (Rising public awareness and media)}

No one disagrees that nowadays, at the international level, there are more effective growth of cultural and tourism services. However, the situation of the local community is outlying of its assumed location, due to the very harsh conditions that the country have been passed during the past decades, which influenced in serious manner negatively on the level of public collective awareness about the significance of heritage and its numerous benefits at various levels: social, cultural and economical and etc.

According to the participants, the public awareness of safeguarding built heritage is inadequate, ${ }^{24}$ and the deficiencies at this level has had its causes, which include the scarcity of non-governmental organizations that supporting the maintenance efforts, lack of appropriate information means to raise awareness among citizens about the preservation, rarely existence of a close relationship between the Directorate and owners of heritage buildings whether public or private sector, lack of voluntarily efforts by citizens and specialists on the maintenance activities, unavailability of any publication attempt to demonstrate a guide of archaeological sites and heritage buildings located in the city, and the decline of cooperation with non-governmental organizations and bodies to conduct surveys and reports on conservation work.

\section{CONCLUSIONS AND RECOMMENDATIONS}

- Different goals, objectives and results of preventive conservation aspects may intersect and share with each other, thus providing one in a specific aspect will be achieved automatically on the other, therefore, multiple difficulties may be resolved by performing one specific part, make it a priority requires rapidity in its implementation, for example currying out a thorough inventory for built heritage in Mosul old city fills the information gap needed for registration, information, risk management and so on, even it could be considered as a training task for the staff and an opportunity for young surveyors to enhance their learning.

- In order to achieve sufficient approach of preventive conservation practice for Mosul heritage several results could be highlighted. For environmental management, it is more

\footnotetext{
${ }^{23}$ Despite of what aforementioned, some participants noted that the Directorate is satisfied with the scientific and technical level of its staff, and that the Directorate currently has carried out pioneering work in the work of the maintenance and preservation at the national level! ${ }^{24} \mathrm{~A}$ frequent question that was presented to officials and specialists in Archeology field that what is the most serious risk faced antiquities in Nineveh/Iraq; their answers were "The danger is the ignorance of citizens and officials of the worth and of monuments and archaeological sites (E- magazine Niqash, 2011).
} 
practical in the circumstances of deterioration of historic buildings to aim for a useful modification of the environmental conditions.

- For the external surfaces in few cases, it will be achievable to manage the environment, while in indoors, within designed and regulated buildings it is possible to plan for environmental control.

- The evaluation of environment is the initial phase for environmental modification, which might include a survey measurement monitoring and analysis of the environmental sources.

- For controlling the environmental sources it is vital to avoid relative humidity and temperature fluctuation; avoid condensation; avoid strong airflow; avoid direct sunlight on the surfaces; and remove salt efflorescence, which are the general steps for best practice for built heritage. Such factors require periodical investigation and diagnosis that represent the permanent required act to obtain preventive conservation goals.

- Regarding registration management process, carrying out a thorough inventory for the built heritage in the old city of Mosul is crucial to overcome listing and reporting requirements needed to present the database to prepare and create risk or emergency plan, which highlights all necessary actions in exact time for the right construction so as to control the risk before its emergence.

- Protecting built heritage requiring individual treatments with thorough preventive conservation over time. Hence, it can be moderated to more controllable levels, putting human capital and investments to further constructive employment.

- The periodical control of the building is the key instrument for an aware protection.

- It is essential to provide supporting system for listing, registration and documentation actions of the historic and heritage properties, beside preparing and improving management information systems particularly the e-media in order to establish both of preventive and curative preservation plan, and utilizing communication technologies in expertise exchanging amongst different involved bodies in the conservation process. Such aspects enable participants, planners, and stakeholders make the proper dissections in this field.

- For the protection of authenticity and assuring the sustainability of heritage buildings and historical, listed architectural properties should be registered in a form of digital representation that contains all of the archaeological, historical buildings and sites with its environments in a systemic format, which holds all remarks and observations of the periodic investigation and its physical changes over time.

- After database acquisition phase, it is essential to develop information management system for Mosul built heritage which could be done by collaboration with research centers and departments of Architecture, Computer Engineering, and Archeology of University of Mosul. Analyzing such information by diagrams, level and time of expected risks and serious 
damage can be indicated, which are needed to perform treatment maintenance. This representation is created by specific computer software as an important part to the revival of urban development.

- All the initial activities of maintenance and monitoring have to be indicated and described in details.

- The chronological scheduling of the interventions is the important planned maintenance matter; consequently such approach should contain a chronic diagram about the activities to be performed, to gather information about executed operations, achieved results and state of the conservation. This system should contain all information about the construction, its characteristics, measurements, plans, materials, photos, risks, documentations, level of damage and degradation of deterioration, rates and result of previous periodical surveys, description of last interventions, and so on.

- Additionally, the directorates should encourage and enhance using current technologies for exploiting the heritage recourses through utilizing the Non-destructive testing techniques for analysis, creating 3D and 4D representations of built heritage, establishing permanent web sites for information exchanging to facilitate decision-making and to raise public awareness.

- The most important of all these aspects may be the education and training management, which has the influence on all others. The education and training of involved participants plays a key role for the success of implemented measures. Persons who are responsible for built heritage managing and caring should be made aware of preventive conservation issues.

- The successful approach to improve or implement preventive conservation should be provided by adequate researches, which combine integrally and compatibly recent and developed methodologies and techniques.

- Interest requests to be raised amongst people to pay attention of their environment with small action as well as to appreciate the value and preserve their traditional activities. Preventive conservation approach begins from inhabitants and without their efforts and assistance such initial care is vanished.

\section{REFERENCES:}

- Beckett B., 2007-2008, High definition digital monitoring of architectural surfaces, University of Bamberg, Germany. Web: www.beckettphotography.com

- Beckett, B. 2008, Details for High definition digital monitoring of architectural surfaces, Seminars on Preventive Conservation and Monitoring of the Architectural Heritage Fontevraud Abbey, France. 
Biagini, C. 2002, Information technology ed automazione del progetto, Firenze, University Press, Italy.

- Building Services Division. 2012, Comprehensive Facilities Maintenance Plan (FMP), September, St. Mary’s County, Department Of Public Works \& Transportation, California, Maryland, USA, September. Pdf online www.stmarysmd.com.

- Cassar, M. 2006, Value Of Preventive Conservation, A Meeting at the Evtek Institute of Art and Design, Vantaa, Finland.

- Dann, N. 2000, the Logic of Maintenance - Context 67. Institute of Historic Building Conservation - September. Web: http://www.maintainourheritage.co.uk/context_nd.htm

- Kenkel, D. S. 1994, the Demand for Preventive Medical Care, Applied Economics Journal, 26, P.313-325.

- Massue, J. P., Schvoerer, M. 2001, Protection of Cultural Heritage, Module B1-4/C, Handbook, School Of Civil Protection, Council of Europe.

- Putt, N., et al, 2004, Teamwork for Preventive Conservation, European Commission Studies: Research Report, ICCROM, London.

- Reccia, E. 2009, Planned Maintenance And Conservation: A Maintenance Plan For Restoration Projects, The Case Study Of Roscigno Vecchia, Unpublished Master's Thesis, University Of Nova Gorica, Venice, Italy.

- Recommendations of International Conference on Preventive Conservation of Architectural Heritage, 29-30 October, 2011, Nanjing, China.

- Sessa, V. M. 2000, La Carta del Rischio del patrimonio culturale: l'esperienza della Lombardia, Aedon, Rivista di arti ediritto on line journal, Mulino, Bologna, Italy, No. 3, Issn: 1127-1345. Online pdf: http://www.aedon.mulino.it/archivio/2000/3/sessa.htm

- Sullivan G. P., Pugh R., Melendez A. P., Hunt W. D. 2010, Operations \& Maintenance Best Practices, A Guide to Achieving Operational Efficiency, Release 3.0, Prepared by Pacific Northwest National Laboratory for the Federal Energy Management Program, U.S. Department of Energy, (a) Efficiency Solutions, LLC August.

- The Charter of Venice for the Conservation and Restoration of Monuments and Sites, 1964, ICOMOS, Venice, Italy.

- The Declaration of Amsterdam, 1975, the European Council of Ministers Committee.

- The Document of Vantaa, 2000, Towards a European Preventive Conservation Strategy adopted at the Vantaa Meeting, Vantaa, Finland, September.

- Tim, P. 2005, How to keep for a while what you want to keep forever, lecture notes for the museology course at Denmark's Library School, April. Web site 01/01/2012: http://www.conservationphysics.org/ 
- Torre, S. D. 2010B, Conservazione programmata: i risvolti economici di un cambio di paradigma, Il Capitale culturale, Studies on the Value of Cultural Heritage, rivista annuale Vol. 1, university of Macerata, Italy.

- Torre, S. D. 2010 C. Learning and unlearning in heritage enhancement processes, ESA Research Network Sociology of Culture Midterm Conference: Culture and the Making of Worlds, Università Bocconi, Milan, Italy.

- Torre, S. D. 2010A. Preventiva, Integrata, Programmata: Le Logiche Coevolutive Della Conservazione, in atti del XXVI convegno internazionale "Scienza e Beni Culturali" Pensare la prevenzione, manufatti usi ambienti, Bressanone, luglio 2010, Arcadia Ricerche, Venezia.

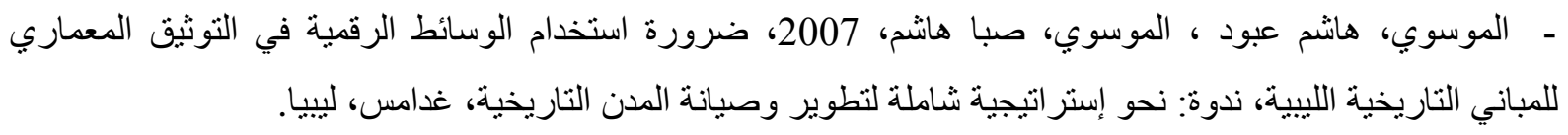

\section{Web Sites:}

- Kathleen D. 2000, et al, Managing the Environment: An Update on Preventive Conservation, Getty organization, newsletters, web site,03/01/2012: http://www.getty.edu/conservation/publications_resources/newsletters/15_2/feature.html

- National gallery of Australia website, 17/01/2012:

http://nga.gov.au/Conservation/prevention/index.cfm.

- Non-destructive techniques, websites, 22/01/2012: http://www.onsiteformasonry.bam.de; http://www.chef.bam.de ; http://www.iter.polimi.it ;

- The J. Paul Getty Trust, 12/01/2012:

http://www.getty.edu/conservation/publications/newsletters/7_1/preventive.html.

- The Sixth Framework Programme of the European Commission, the SPRECOMAH project, website, 6,12,2011: http://www.sprecomah.eu/site/

- International council of Museum website: 10/10/2011:

http://www.icom-cc.org/36/Preventive\%20Conservation/

- PRECOMOS 10/12/2011 website: http://precomos.org/

- MonumentenWacht website, 23/12/2011: http://www.monumentenwacht.be/

- E- magazine Niqash, 05/01/2012: www.niqash.org/

- Salzwiki website, 14/1/2012:

http://193.175.110.91/salzwiki/index.php/Pr\%C3\%A4ventive_Konservierung 
Table 1: Preventive conservation aspects and the required actions (The researcher).

\begin{tabular}{|c|c|c|c|}
\hline & Preventive Conservation Aspects & Main Action & Minor Actions \\
\hline 1 & $\begin{array}{l}\text { - Reducing the impacts of destructive } \\
\text { factors }\end{array}$ & $\begin{array}{l}\text { Environmental } \\
\text { management }\end{array}$ & -Environmental control \\
\hline 2 & $\begin{array}{l}\text { - Preventing the damages \& avoiding } \\
\text { harms }\end{array}$ & Risk management & $\begin{array}{l}\text {-Preparing emergency } \\
\text { planning }\end{array}$ \\
\hline 3 & $\begin{array}{l}\text { - Recognizing \& assessing the built } \\
\text { heritage values }\end{array}$ & $\begin{array}{l}\text { Documenting } \\
\text { management }\end{array}$ & $\begin{array}{l}\text {-Registration } \\
\text {-Listing } \\
\text {-Reporting }\end{array}$ \\
\hline 4 & - Identifying the damages progression & $\begin{array}{l}\text { Schedule investigation } \\
\text { management }\end{array}$ & $\begin{array}{l}\text {-Inspections } \\
\text {-Diagnosis } \\
\text {-Surveys }\end{array}$ \\
\hline 5 & $\begin{array}{l}\text { - Controlling the institutions } \\
\text { cooperation \& identifying their } \\
\text { responsibilities }\end{array}$ & Information management & $\begin{array}{l}\text {-Information } \\
\text { exchanging } \\
\text {-Representing }\end{array}$ \\
\hline 6 & $\begin{array}{l}\text { - Controlling Various Types Of } \\
\text { Interventions }\end{array}$ & Regulation management & $\begin{array}{l}\text {-Law } \\
\text {-Amendments } \\
\text {-Legislations }\end{array}$ \\
\hline 7 & - Skills Development & $\begin{array}{l}\text { Human resources } \\
\text { management }\end{array}$ & $\begin{array}{l}\text { - Training } \\
\text { - Teaching \& } \\
\text { educational aspects }\end{array}$ \\
\hline 8 & - Awareness improvement & $\begin{array}{l}\text { Communication } \\
\text { management }\end{array}$ & $\begin{array}{l}\text {-Public awareness } \\
\text {-Media }\end{array}$ \\
\hline
\end{tabular}

\section{S.I.R.Co.P. framework}

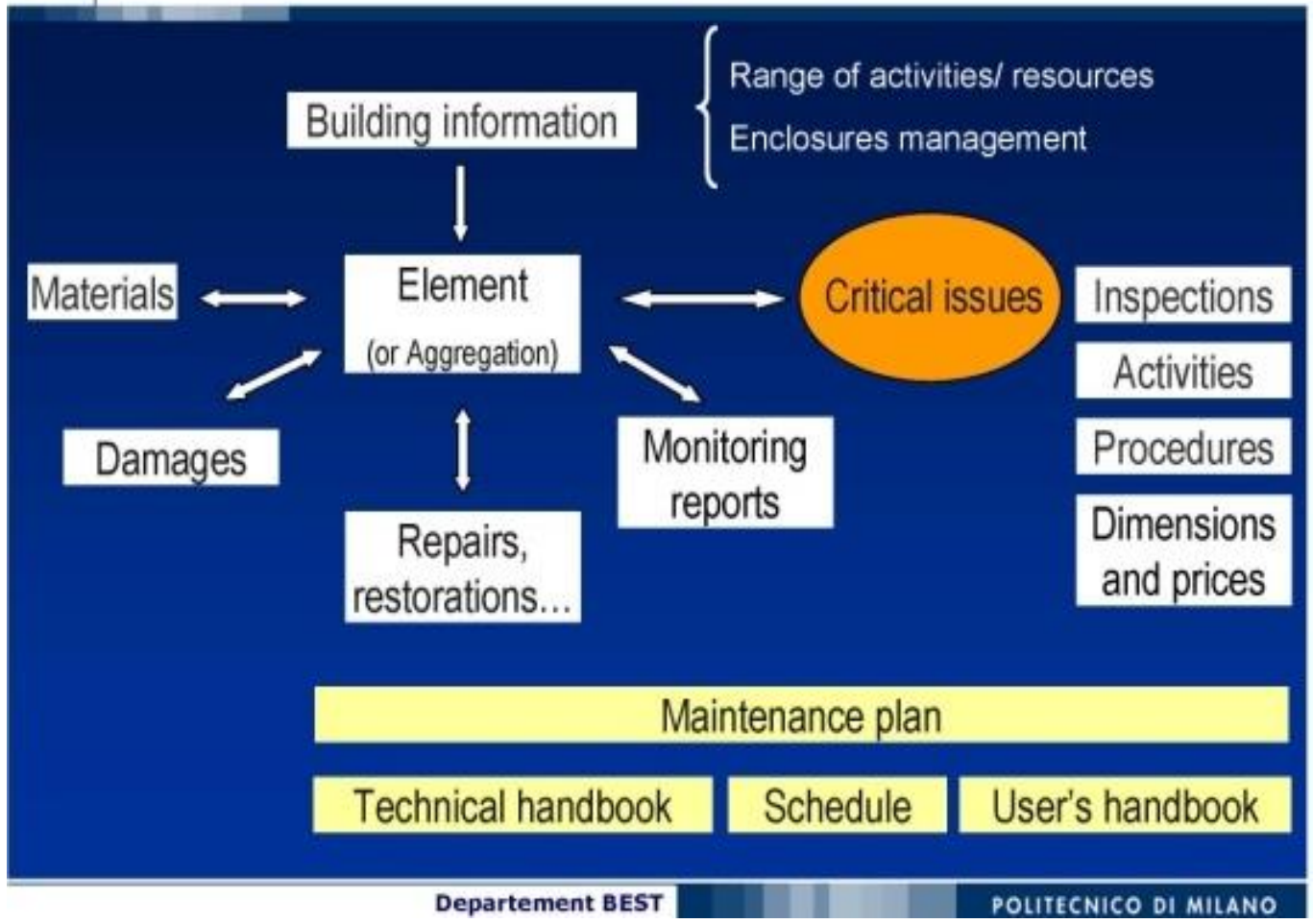

Fig. (1): The framework of the Regional Information Conservation (SIRCOP) (SPRECOMAH website). 


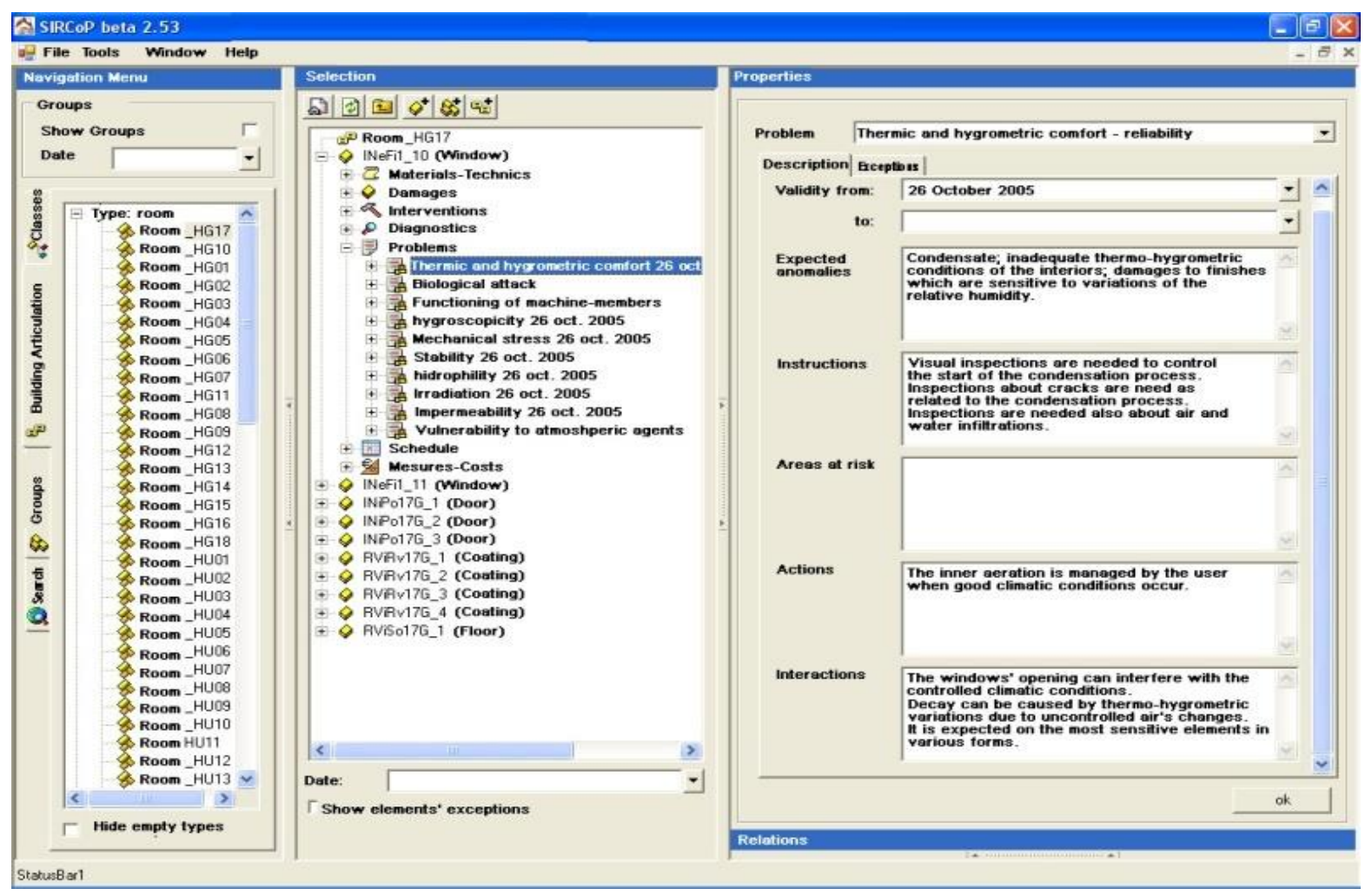

Fig. (2):- Critical issues of one element (window) System for Planned (SPRECOMAH website).

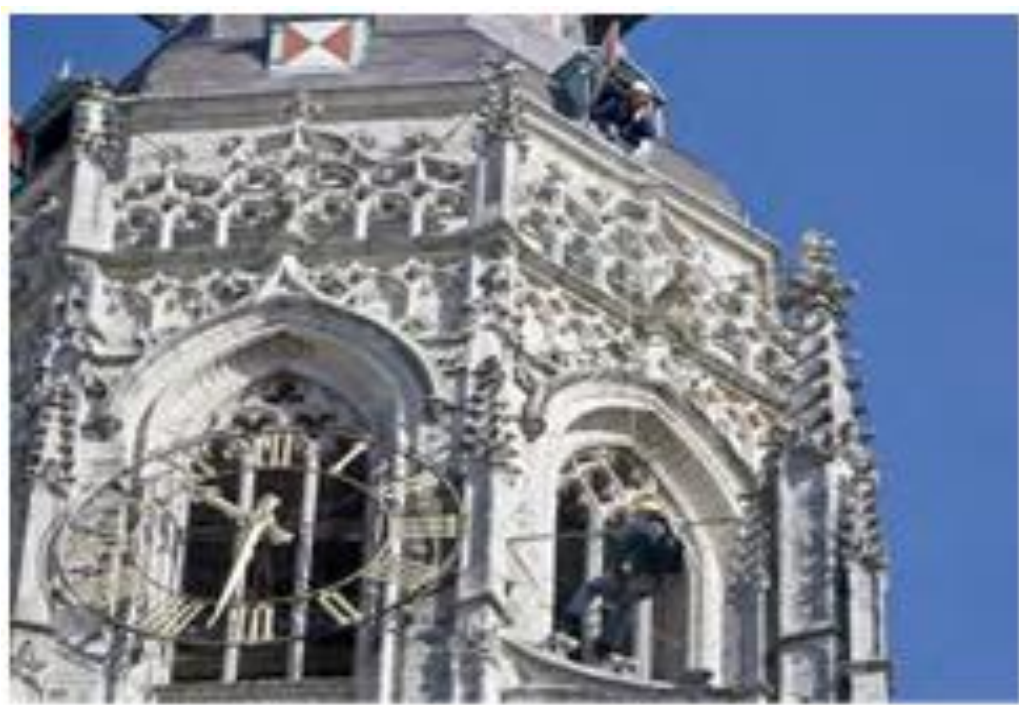

Fig. (3):- All parts of the monument must be examined thoroughly (SPRECOMAH website). 


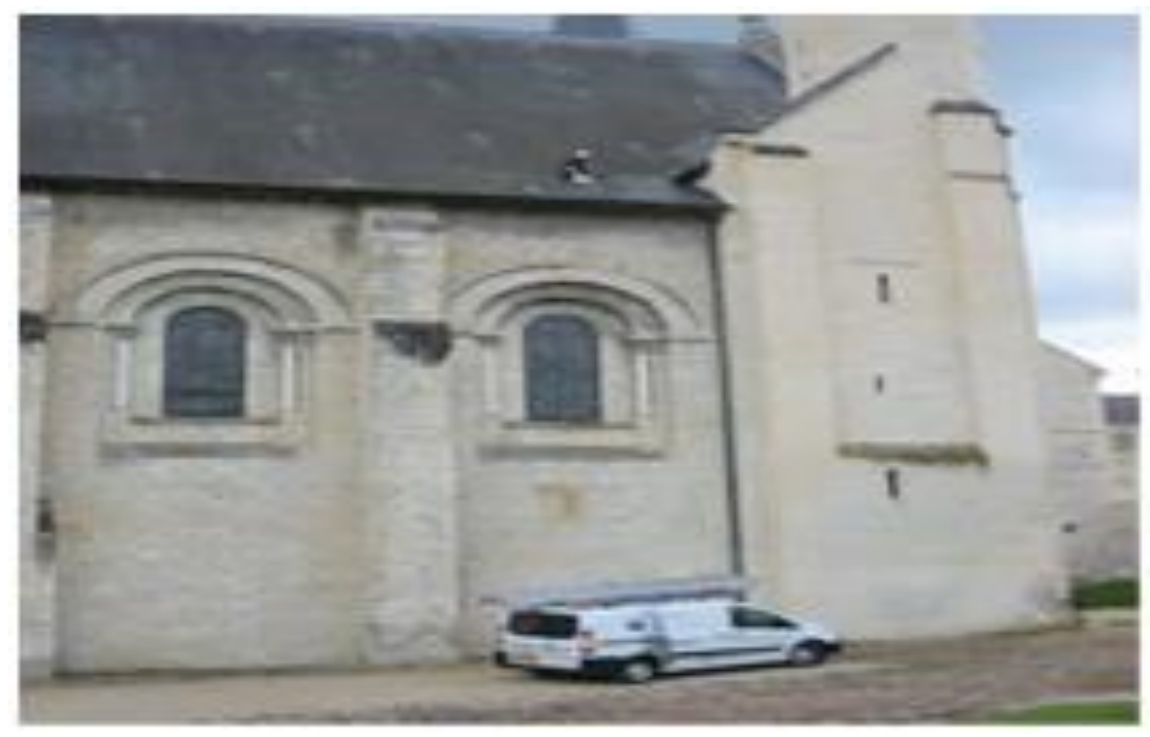

Fig. (4):- International cooperation: inspection of the Abbey of Fontevraud in Saumur (France) by the Dutch Monumentenwacht (SPRECOMAH website).
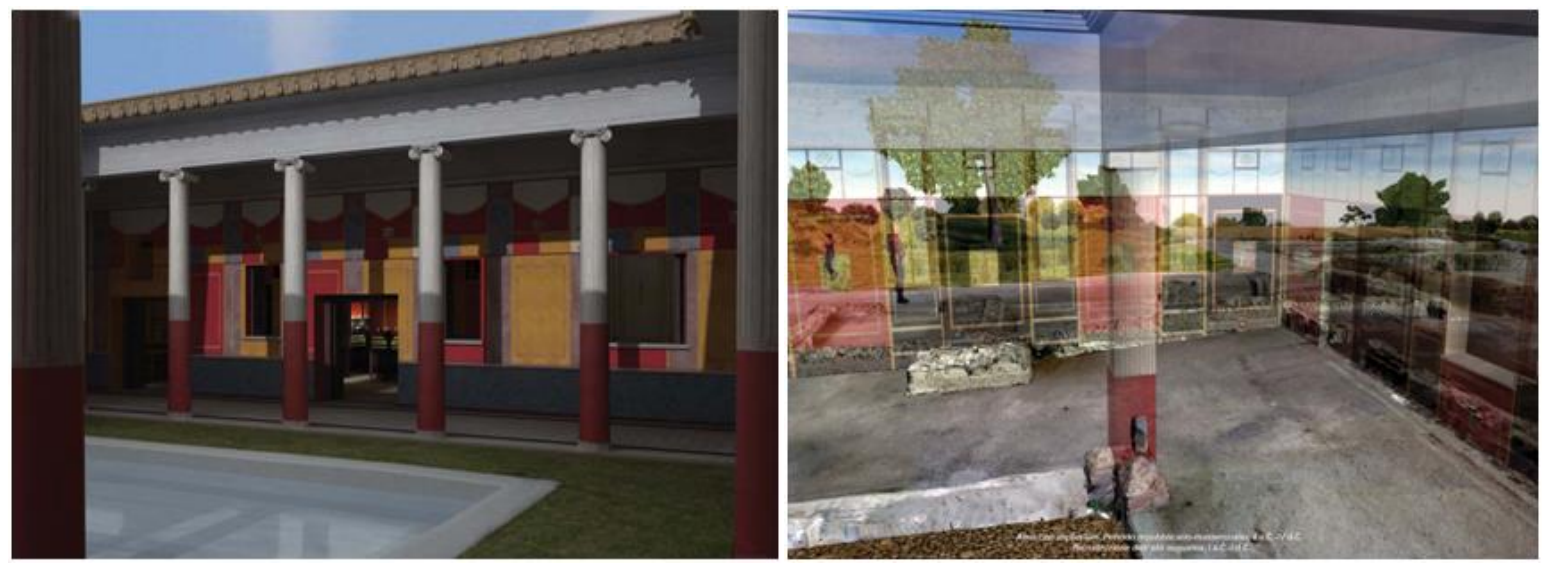

Fig. (5):- 3D Representation of the built heritage.

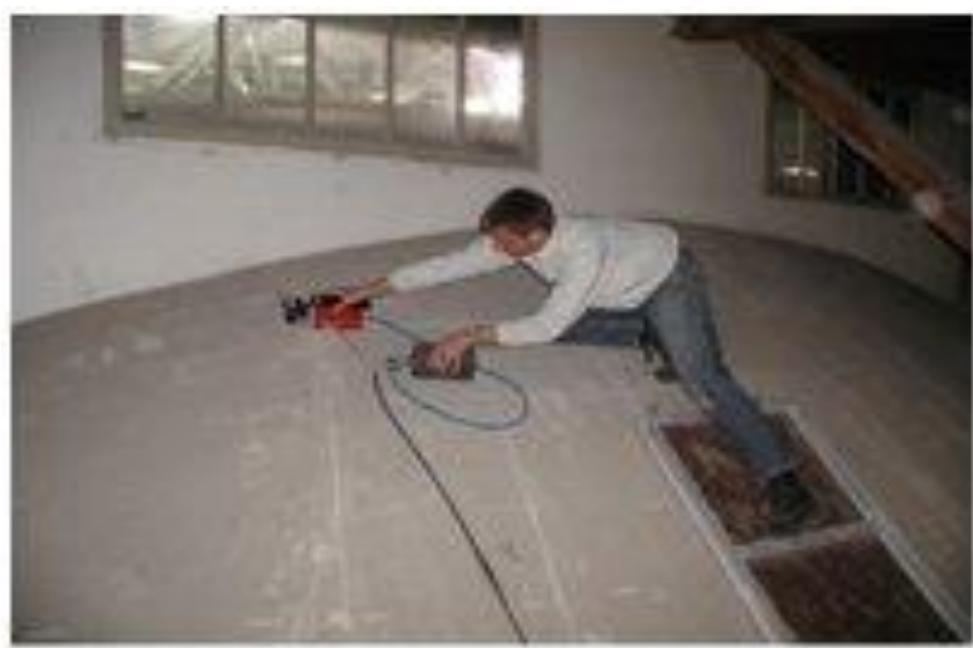

Fig. (6):-Recording of radar data at the top of the cupola of the Altes Museum in Berlin (SPRECOMAH website). 


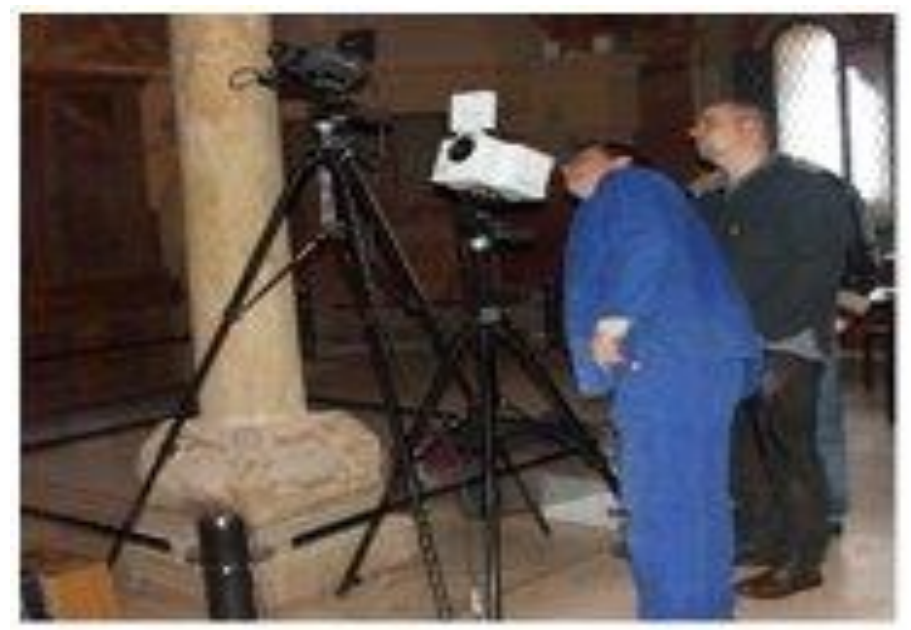

Fig. (7):-Application of active thermography at the Wartburg in Eisenach (SPRECOMAH website).

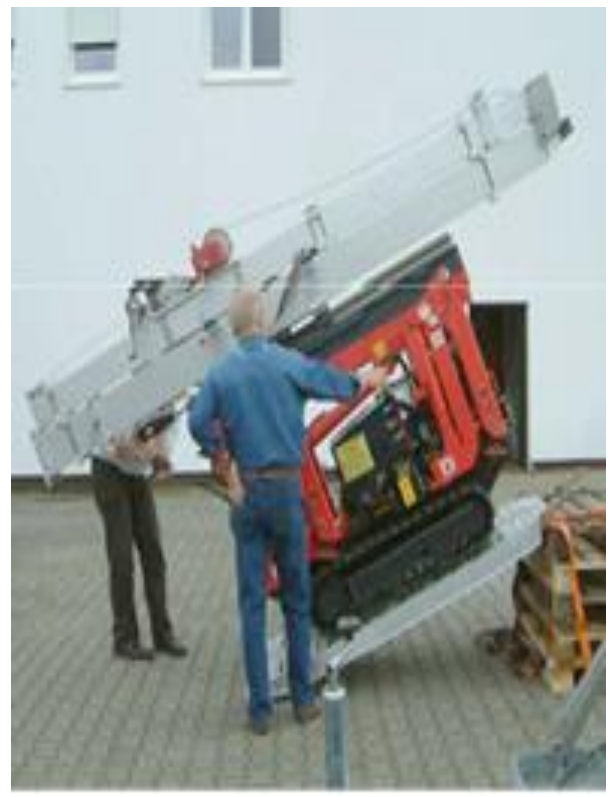

Fig. (8):- RRS System during construction (Beckett, 2008).

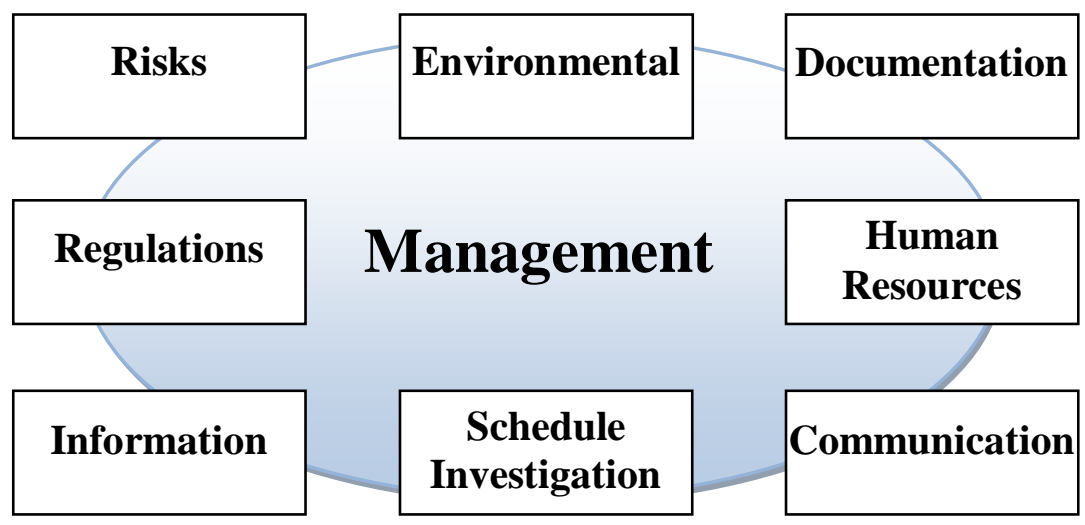

Fig. (9):-The main aspects of the preventive conservation (The researcher). 


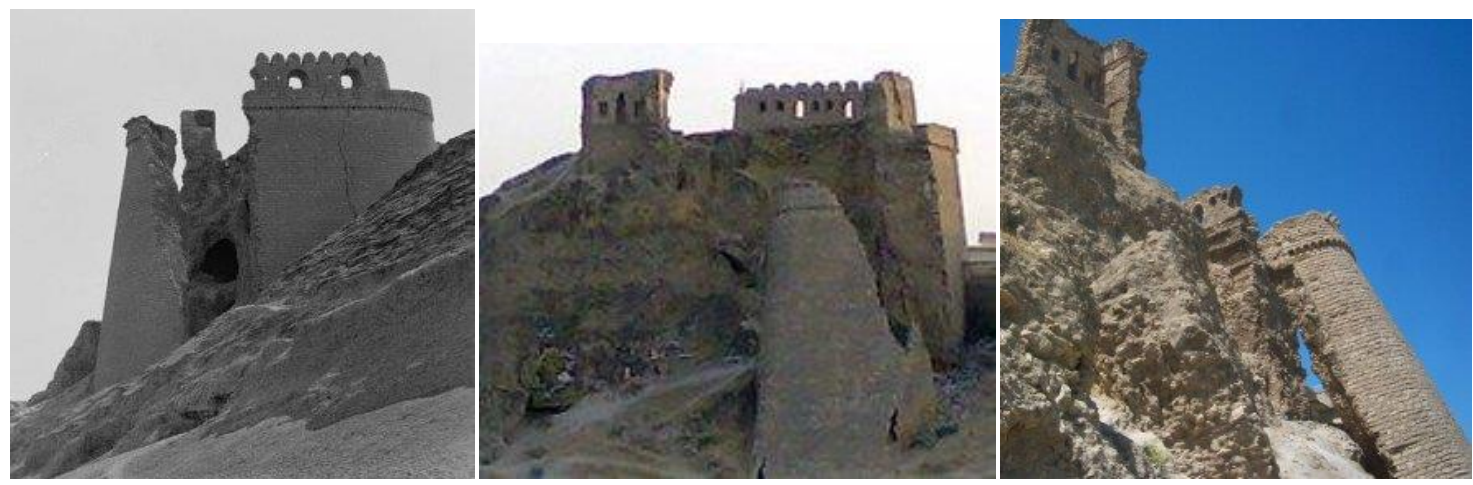

Fig. (10):-The Gradation of deterioration over time in castle of Bashtabia in Mosul. Right: current situation.

\section{Appendices:}

Appendix 1: Questionnaire form

\begin{tabular}{|c|c|c|c|}
\hline الملاحظات والتعليقات & y & |نعم & والتراثية لمدينة الموصل، هل الحفاظ العمراني على الممتلكات الثقافية والتاريخية \\
\hline & & & - تتوفر خطة عمل للصيانة الوقائية Preventive maintenance \\
\hline & & & - تسبق عمليات الصيانة العلاجية خطوات للصيانة الوقائية \\
\hline & & & - تتوفر عمليات تخطيط وبرمجة لأعمال الصيانة \\
\hline & & & - دقة التقديرات الخاصة بموعد ظهور العيوب هي جيدة \\
\hline & & & - يتم تسجيل الملاحظات الخاصة بأعمال المسوحات في سجلات خاصة \\
\hline & & & - تتوفر معدلات أعمال الصيانة الخاصة بالمباني والتسجيلات السابقة لها \\
\hline & & & - تنوفر كتابيا تثارير بنوع الأضرار المنكررة للمنشآت التاريخية أو التراثية \\
\hline & & & - هناك كثوفات لتحديد موعد ظهور العيوب بالمبنى ونوعيتها \\
\hline & & & - هناك كثوفات لتحديد أعمال الصيانة المطلوب تتفيذها بالمبني \\
\hline & & & - هناك كثوفات لتحديد حجم أعمال الصيانة والتكاليف اللازمة لتتفيذها \\
\hline & & & - هناك كثوفات لتحديد أعداد ونوعية العمالة المطلوبة لأداء العمالة \\
\hline & & & - هناك كثوفات لتحديد الزمن اللازم لأداء كل نثاط من أنثطة الصيانة \\
\hline & & & - هناك كثوفات لتحديد المواد والخدمات المطلوبة لأداء أعمال الصيانة \\
\hline & & & - أن دور الأشراف الهندسي والإدارة الهندسية دورا أساسيا وملزما \\
\hline & & & 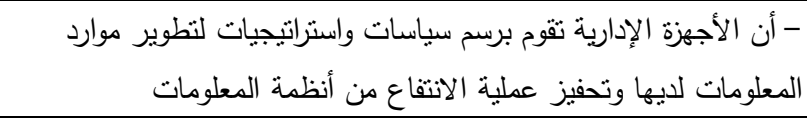 \\
\hline & & & - هناك نمو أكثر فاعلية في الخدمات الثقافية والسباحية \\
\hline & & & - تتوفر منظومة معلومات رقمية للممتلكات التراثية والتاريخية \\
\hline & & & - يراعى حماية مجاورات المبنى التراثي المنفرد ونسيجه ضمن بيئته \\
\hline & & & - يقتصر الحفاظ على ترميم المبنى التزاثي دون مجاوراته \\
\hline & & & - يوجد تمويل كاف نسبيا لأعمال الحفاظ \\
\hline & & & - النتريعات الخاصة بالحفاظ ملائمة وكافية \\
\hline & & & - توجد منظمات غير حكومية داعمة لأعمال الحفاظ \\
\hline & & & - أن الوعي العام لأعمال صيانة التزاث واف \\
\hline
\end{tabular}


PREVENTIVE CONSERVATION AS A PROCEDURE FOR SAFEGUARDING MOSUL BUILT HERITAGE

\begin{tabular}{|c|c|c|}
\hline & & - تنتوفر السبل الإعلامية الملائمة لنشر الوعي بين المواطنين حول أعمال \\
\hline & & بالمباني التراثية البرامج الحاسوبية المستخدمة لأغراض إدارة المعلومات الخاصة \\
\hline & & - يتوفر الكادر الملائم بالعدد والكفاءة لأعمال الصيانة والحفاظ \\
\hline & & - - تمنالك المديرية علاقات قوية مع مؤسسات الدولة ذات العلاقة وبما يخدم \\
\hline & & - السياسة المنبعة في أعمال الصيانة وقائية فقط - قبل حدوث الضرر \\
\hline & & - السياسة المنبعة في أعمال الصبانة علاجية فقط - بعد حدوث الضرر \\
\hline & & - مبادرات تعاون مع خبرات خارجية لأغراض نطوير كفاءة الكوادر وسياسات \\
\hline & & - تم تطوير الأدوات والأجهزة والتقنيات بما يتلاءم مع التقدم العالمي في أعمال \\
\hline & & - إرسال الكوادر خارج القطر لأغراض تحسين وتطوير الكفاءات \\
\hline & & - تمنلاك المديرية بسجلات خاصة بأصحاب المهن والحرفيين الخاصين بالبناء \\
\hline & & - تم إجراء ورشات عمل داخل القطر لكوادر المديرية لأغراض تطوير \\
\hline & & - تم إجراء دورات تدريبية عملية وبمساعدة الحرفيين التقليدين لفنيين حديثي \\
\hline & & - نفذت المسيرية أعمال رائدة على مستوى القطر في أعمال الصيانة والحفاظ \\
\hline & & - أن المديربة راضية عن المستوى العلمي والفني للكادر \\
\hline & & - نتوفر مسوحات ذات الحد الأدنى لأعمال الصيانة والترميم بشكل كفوء \\
\hline & & - نتوفر دراسات وبحوث حديثة لدى المديرية عن أعمال الحفاظ والصيانة \\
\hline & & - لدى المديرية موقع الكتروني دائم يتم التواصل من خلاله مع الجهات ذات \\
\hline & & لعرض لدى المديرية موقع الكتروني دائم يتم التواصل من خلاله مع المواطنين \\
\hline & & أو الخاص المديرية علاقة وطيدة مع ممنلكي المباني التراثية سواء من القطاع العام \\
\hline & & - على أعمر جه طوعي من قبل بعض المواطنين المتخصصين لإعانة المديرية \\
\hline & & - يتوفر عدد كاف من المساحين لدى كوادر المديرية \\
\hline & & - إإبداء المشيرية بحاجة عادة إلى المؤسسات الحكومية الأخرى لإجراء المسوحات \\
\hline & & هل تقوم كوادر المديرية: \\
\hline & & - بالكثف الدوري للبحث عن الأضرار في المنشأ \\
\hline & & - الكثف والمراجعة على فترات زمنية محددة مسبقا على جميع العناصر \\
\hline & & - استخدام الوسائط الرقمية في التوثيق \\
\hline & & - حصر للآثار والمواقع التاريخية في المدينة \\
\hline & & - - إنشاء قواعد البيانات الآلية لكافة المباني التاريخية والأثرية \\
\hline & & - تدريب العاملين بمراكز الدراسات والبحوث الأثربة على استخدام الحاسبات \\
\hline
\end{tabular}


PREVENTIVE CONSERVATION AS A PROCEDURE FOR SAFEGUARDING MOSUL BUILT HERITAGE

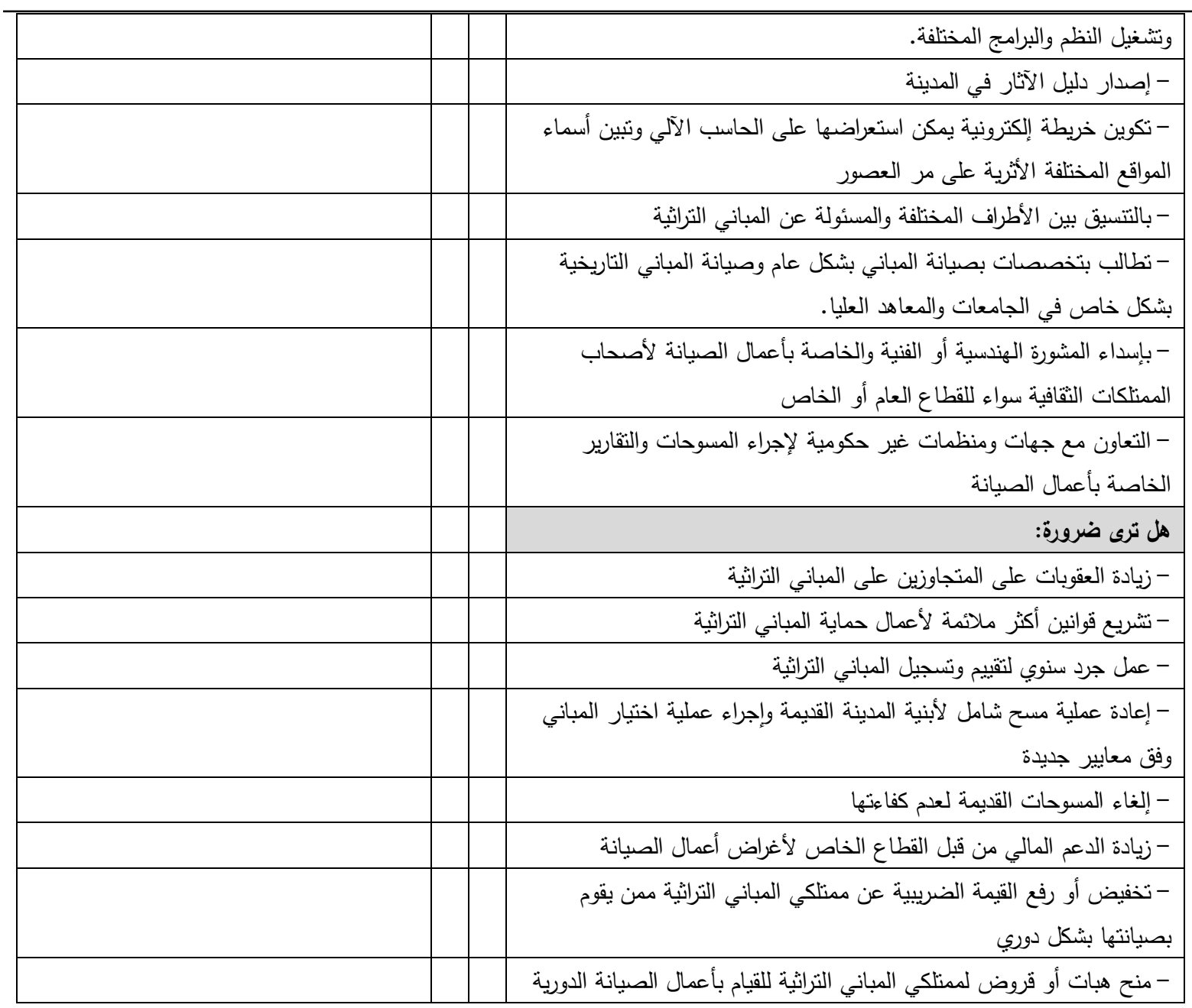

المديرية:

المنصب الإداري:

الاسم:

التاريخ 


\title{
الحفاظ الوقائي كمنهية لحماية التراث العمراني لمدينة الموصل القديمة
}

\author{
عماد هاني العلاف \\ مدرس، قسم الهندسة المعمارية، كلية الهندسة، جامعة الموصل، العراق
}

الخلاصة:

بعد نجاح عدة تجارب على الصعيد العالمي بتنبي مناهج الحفاظ الوقائي لأغراض حماية وصيانة التراث

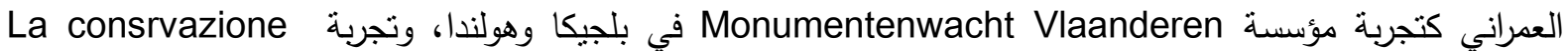
لدقاطعة لومبارديا في ايطاليا، تحاول العديد من البلدان اتخاذ إجراءات مشابهة لحماية نراثها العمراني لدرهي المحلي. خلال العقود الثلاثة الماضية اندثر العديد من المباني التراثية والتاريخية في مدينة الموصل القديمة باضطراد والذي يعزى إلى القصور أو النقص في منهجيات المراقبة والسبطرة الخاصة بأغراض حماية هذه المنشآت الاستثنائية غير بالئه القابلة للاسترداد. يصف الحفاظ الوقائي أعمال البحث والتخخلات التي تهدف إلى تخفيف معدل التداعي وتقليل الخطر الذي يتعرض له المنشأ بمرور الوقت، فهو يسعى إلى تحديد وتقليص المخاطر المحتملة للعناصر العمرانية من خلال السيطرة المفصلة والثاملة للمجاورات والبيئة المحيطة، ويحاول التخفيف والسيطرة على عملية حدوث الضرر والتهرؤ من لهن خلال البحث وتوظيف الأساليب التي تعمل على تعزيز سلامة العناصر والمباني المعمارية وتفاعلها مع المجتمع، فهو

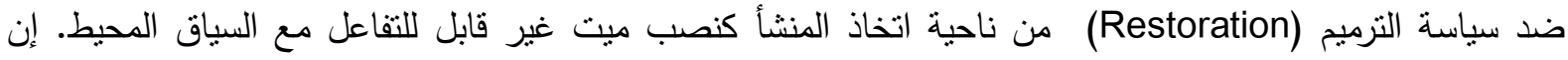
غياب سياسة حفاظ وقائية واضحة وناجعة للمؤسسات المسئولة عن أعمال حماية التراث العمراني العراقي بشكل عام ومدينة الموصل القديمة بشكل خاص هو قضية حاسمة ومهمة. يهدف البحث إلى إجراء عملية مقارنة بين سياسة الحفاظ الحالية لهذه المؤسسات مع مثيلتها العالمية للوقوف على أهم نقاط الخلل والضعف في سياسة الحفاظ الوقائي المحلية، كما لئه يهدف إلى تقديم خطوط دلالية وتوصيات لإعداد إستراتيجية حفاظ وقائي لتراث المدينة العمراني. تعتمد منهجية البحث

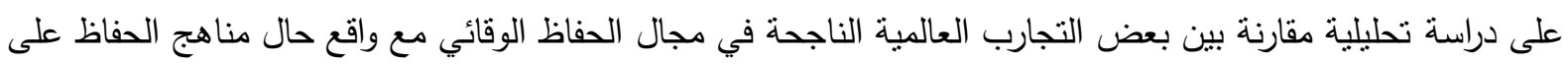
تراث مدينة الموصل.

الكلمات الدالة: مبادئ الحفاظ المعماري، الحفاظ الوقائي، السياسات التطبيقية، التراث العمراني، مدينة الموصل القديمة. 